\title{
7. Democratizing urban policy in Brazil: participation and the right to the city
}

\author{
LEONARDO AVRITZER
}

Brazil underwent an intense process of urbanization during the twentieth century. At the beginning of the century, over 70 per cent of the population inhabited the countryside; by the end, more than 70 per cent were urban dwellers. In the process, Brazilian cities grew in an unfair, disorderly and illegal way. The unfairness was the result of a process of modernization with either no planning, or planning that assigned no space to the poor population, as was the case of Belo Horizonte and Brasília (Brasil 2004; Caldeira 2000). In these planned cities, the poor population had to occupy urban plots of land illegally. The disorderliness arose from an absurd process of land concession during colonial and imperial periods that created legal chaos in large cities such as São Paulo and Rio de Janeiro (Holston 1993). The illegality was due to a civil code written in 1916, crafted for a rural society, which did not provide adequate legal instruments for urban policy development as the country modernized (Fernandes 2002). The result was an urbanization process that ran completely out of control at the peak of Brazil's economic growth during the seventies.

The late seventies and early eighties in Brazil, the last years of the authoritarian regime, saw the constitution of a democratic civil society. Brazilian civil society reorganized itself, claiming many public goods and policies, among them access to urban land and property in large Brazilian cities (Gohn 1991). The issues of access to property and property legalization are at the origin of the housing movement in the city of São Paulo. In other parts of Brazil, such as Porto Alegre, the issue of the legalization of state land occupied in the fifties was more pressing (Baierle 1998). In both cases, and in Belo Horizonte, the relationship between legal and illegal cities would come to the fore and would motivate the organization of hundreds of neighbourhood associations in capitals of the south and south-east of Brazil. The associative drive of the late seventies in Brazil was more selective and contingent on local context in state capitals of the north-east.

In this chapter I will discuss the emergence and achievements of a 
civil society movement in Brazil, the Movimento Nacional para Reforma Urbana (MNRU, National Movement for Urban Reform). This movement emerged during the National Constituent Assembly and is still active in Brazil under its newer designation of Fórum Nacional para Reforma Urbana (FNRU, National Forum for Urban Reform). It is one of the few cases in democratic Brazil of a national civil society movement. The MNRU was active in the constitution-making process, and later the FNRU secured the approval of the required infra-constitutional legislation on urban reform. ${ }^{1}$

Comparing the situation of the urban poor in Brazil twenty years ago and its situation today, the following changes stand out. In 1984, the last year of authoritarianism in Brazil, 64 per cent of Brazilians had access to treated water and 40 per cent to sewerage. In the wealthy south-eastern region, 82 per cent of the population had access to treated water and 55 per cent to sewerage. Today, the situation is much better owing to the actions of urban social movements and administrations led by progressive politicians. In 2002, 82 per cent of Brazilians had access to treated water (in the south-eastern region, 91 per cent) and 48 per cent of the population to sewerage systems ( 76 per cent in the southeastern region) (Instituto Brasileiro de Geografica e Estatistica 2003). The urban reform movement gave legal instruments to local governments to implement these changes. State capacity to curb speculation in large Brazilian cities was very low at the end of the authoritarian regime, as was state capacity to legalize occupations by the poor population. Today, every large Brazilian city has specific legislation allowing it to grant usage rights of state land to the poor, which in the long run will reduce the formation of new slums. Last but not least, few Brazilian capitals, except Porto Alegre, had a medium-term development plan. Today, all Brazilian cities with over twenty thousand inhabitants have City Master Plans (CMPs).

These changes should not be underestimated. The poor population in Brazilian cities has acquired access to public goods and increased its access to housing in the last twenty years. The changes are linked to the movement for urban reform in Brazil and its actions at both national and local levels.

Despite the depth of these changes, urban reform in Brazil was not a 'high mobilization' case, such as the agrarian reform or budget reform movements. The latter movements brought about change in Brazil through road blockages, illegal invasion of lands and intense mobilizations in cities. In contrast, the urban reform movement used the influence of its most important partners to mobilize resources 
and influence at the political level, in particular in the National Congress.

In the first part of the chapter I show how informal movements of public action constituted a movement for urban reform, discussing the different organizational configurations assumed by the urban reform movement from the early eighties to 2000. Second, I narrate how urban reform legislation emerged during the constitution-making process, and after the Constituent Assembly, as the need for infra-constitutional legislation became clear. I go on to discuss the legal and political disputes that took place in the Brazilian Congress over approval of the Statute of the City, and conclude by discussing how the Statute of the City is being implemented in three different cities with different social movement trajectories: São Paulo, Salvador and Porto Alegre. Based on the different cases, I propose a typology of the effectiveness of national civil society in local contexts.

The overall claim of the chapter is that civil society contributed in two capacities to the emergence of the new urban legislation in Brazil. First, through its capacity to gather popular actors and specialists, it created an agenda for Brazilian political society; and second, it had the capacity to influence the Brazilian Congress in the long term. Members of the Brazilian Congress do not stay in the house for long, and the MNRU and FNRU's long-term influence on Congress from 1986 to 2002 was a key success factor in the approval of the Statute of the City.

\section{Social movements, constitution-making and legal change in Brazil}

Urban reform was already on the agenda of the Brazilian left and progressive sectors by the end of the first democratic period in Brazil (1946-64). In 1963 a first national conference for urban reform took place, after which the issue would have to endure twenty years of authoritarianism before returning to the political agenda.

The emergence of urban social movements was one of the novelties of Brazilian democratization. In the first democratic period, associative tendencies among the urban poor were low, with very few neighbourhood associations created (Avritzer 2000; Boschi 1987; Singer and Brandt 1980); those created were leisure associations. The only exception in that period was Porto Alegre, which has the oldest tradition of neighbourhood associations in Brazil (Baierle 1998).

The 1975-85 democratization period changed this picture. Associative patterns greatly increased. In the cities of São Paulo, Rio de Janeiro, Belo Horizonte and Porto Alegre there was a huge increase in the creation of 